\title{
Social Work Education in Northeast India: Status and Challenges
}

\author{
Joseph Riamei \\ Tata Institute of Social Sciences, India \\ *Corresponding Author: josephtiss@gmail.com
}

\begin{abstract}
Social Work Education in the Northeast region of India began only in the year 1992. Since then a number of institutions have come forward to offer Bachelors, Masters' and Doctorate programmes and studies in the discipline. This article captures the history of twenty two recognised institutions offering social work programmes in the region and draws out key empirical issues pertaining to course curriculum, field work and the concretisation of social work as a recognised profession within the said context.
\end{abstract}

Keywords Social Work, Northeast, India

\section{Introduction}

The journey of Social Work profession in India began with the first school of social work namely the Sir Dorabji Tata Graduate School of Social Work (now known as the Tata Institute of Social Sciences) established in Mumbai in 1936. Since then there has been many shifts in its practice and approaches with the changing realities. There has also been explosion of Social work education Institution in India. The growth and promotion of social work education in India was recognised with the University Grants Commissions (UGC) appointing the First Review Committee for Social Work Education in 1965 and the Second Review Committee in 1980 for the promotion, maintenance of standards of education, coordination of social work education, training, research and practice. In 2001 the third review committee sought the need of relating social work education to the social realities. It recommended the curriculum to be divided in three sets. These are: 1) Core set includes the philosophy, ideology, values, ethics, theory and concepts. 2) The supportive set deals with knowledge and skills to assist the core set. 3) The interdisciplinary set includes theories, concepts from other disciplines which relates with social work according the students choice (Thomas, 2010).

Rao (2013) noted that Social work educational institutions were traditionally the centres for knowledge production in the early decades. Since the 1980s, there has been gradual emergence of research and knowledge production outside social work educational institutions. Non Governmental Organisations (NGOs) have contributed a great deal to the production of social work knowledge. The emergence of new modes of knowledge production, for example various tools used for assessing impact, vulnerability, organizational strength of NGOs, Self Help Groups (SHGs), protection of human rights, developed by other than social work academia and practitioners, was expected to alter the discourse about the perspectives and substantive contents of social work education in India.

Seventy five years of Social Work education journey is marked with experimentation, expansion, stagnation and sudden explosion of social work institution. There are about 350 schools in India as per the sources gathered from experts of social work from across the country. Among those Karnataka marked with 72 schools/departments, Maharashtra marked with 60 and several south Indian states occupied large number of social work institutions. Jammu \& Kashmir, Uttarakand, Himachal Pradesh, Assam, Meghalaya, Mizoram, Manipur and Bihar only marked with one school/department and there are no schools at all in five of the Northeast States (Botcha, 2012). Social work as a profession has grown considerably over the last twenty years. Yet, the fact that the concept of social work as a profession did not grow in India but came by a process of cultural borrowing has had its consequences in the manner of its development. There is a great gap between the ideas of the professional social worker and the ideas that inspire the traditional forms of social endeavour. To a certain extent this gap has been sought to be bridged by the suggestive power of such words as sciences and training (Gore 2011)

Professional social workers in India are engaged in development and welfare activities, from micro to macro levels, by governmental, voluntary, corporate and international organisations, and also through people oriented community based social movements and action groups. Social work profession works towards empowerment of marginalised and vulnerable groups, actualising their rights by democratisation of social systems. The profession is guided by secular professional values of human dignity, human rights and social justice that promote self worth, people's participation and self determination, democratic 
pluralism, local self governance, and peaceful collaborative social relationships. In the current times there have been lots of debates and deliberation on the approach of professional social work. As Bodhi (2011) observed that, efforts to insert liberator and emancipator elements into Indian Social Work education, are now visible and are being articulated in the public domain. Most of these efforts are emanating from critical social workers who have become wary of the perils and hypocrisy of traditional social work and its role in fueling and maintaining the status quo. The lack of insight into the oppressive nature of its practice and the present operational perspectives, the lackadaisical attitude adopted towards introspection into existing lacunae and the reluctance exhibited towards truthful 'soul searching' for seeking alternative is very disturbing.

India's Northeast region is popularly celebrated for its cultural diversity and also well known for numerous of problem ranging from conflict, governance issue to insurgencies. Education system in Northeast has not gone beyond the border of traditional social sciences for many decades. Like the sudden explosion of Social Work education in other region of India in 1960s and 70s, for the past decade especially during 2005-2010 there has been sudden blooming of Social Work profession offered by Government and Private Institution in Northeast. Needless to say Social Work education was neither recognised as profession nor a professional practice like other professional course by the people in the region. Though there has been escalating numbers of Institution offering social work education there is considerable challenges and tasks ahead. Social Work education can play a vital role in many different ways and can act as a changing agent in numbers of field from Helath, Education, Livelihood, Peace Building and so on. There is also a great potential to do research and documentation which can result in unlocking the issues which are pertinent in the changing realities. Unlike the other social sciences, a trained social work professional has a great potential to engage in different level and change the realities especial of the poor, marginalised and down trodden people. Social Work profession traces its central tenets of helping vulnerable and oppresses groups in society to the efforts of many historic figures. This profession especially in the context on Northeast region is still in its cradle stage and care must be taken in its curriculum, approaches and methodology so as to become a catalyst profession that is the need of the hour in the region.

\section{Status of Social Work Education in Northeast}

As shown in the table below social work education in the region was introduced by Assam University in 1997 and currently the university is offering Bachelor of Social Work (BSW), Master of Social Work (MSW) and Mphil and PhD programme in Social Work. Mizoram University was the second university that started offering Social Work education in the year 2008 and the university also presently offers MSW, Mphil and PhD programme. These two universities were the only university till late 90 s and early 2000 that offer social work education in the region. Lokopriya Gopinath Bordoloi Regional Institute of Mental Health (LGBRIMH) is another regional institute that offers Mphil in Psychiatric Social Work in the region for quite a long time now. The recognition of Social Work as a profession was not well known in the region for many decades like in the other regions of the country. Interestingly by 2005-2012 there has been unexpected blooming of social work education offer by Government and Private Institution. Currently there are twenty two Institutions/Universities that offer social work education and 15 of these institutions started by 2006 onwards. 
Table 1. Social Work Education Institute/University in Northeast India ${ }^{1}$

\begin{tabular}{|c|c|c|c|c|c|}
\hline $\begin{array}{l}\text { Sl. } \\
\text { No }\end{array}$ & Name of Institute/University & State & Programme Offered & Recognition & $\begin{array}{c}\text { Year of } \\
\text { Establishment }\end{array}$ \\
\hline 1 & Assam University & Assam & BSW, MSW, Mphil and PhD & Central & 1997 \\
\hline 2 & Mizoram University & Mizoram & BSW, MSW, Mphil and PhD & Central & 2002 \\
\hline 3 & $\begin{array}{c}\text { LGBRIMH } \\
\text { Dept. of Psychiatric Social Work }\end{array}$ & Assam & $\begin{array}{l}\text { MPhil in Psychiatric Social } \\
\text { Work }\end{array}$ & Regional Institute & 2009 \\
\hline 4 & Martin Luther Christian University & Meghalaya & BSW \& MSW & State & 2006 \\
\hline 5 & St. Edmund's College, Shillong & Meghalaya & BSW \& MSW & $\begin{array}{l}\text { Affiliated to North Eastern } \\
\text { Hill University (NEHU) }\end{array}$ & 2006 \\
\hline 6 & Bosco Institute & Assam & MSW & $\begin{array}{c}\text { Affiliated to Dibrugarh } \\
\text { University }\end{array}$ & 2008 \\
\hline 7 & Women's College & Meghalaya & BSW & Affiliated to NEHU & 2008 \\
\hline 8 & College of Social Work & Manipur & BSW & $\begin{array}{l}\text { Affiliated to Manipur } \\
\text { University }\end{array}$ & 2009 \\
\hline 9 & $\begin{array}{c}\text { Indira Gandhi National Tribal } \\
\text { University }\end{array}$ & Manipur & BSW \& MSW & Central & 2010 \\
\hline 10 & $\begin{array}{l}\text { Mahatma Gandhi Institute of } \\
\text { Education and Development }\end{array}$ & Nagaland & BSW & Collaboration with IGNOU & 2010 \\
\hline 11 & Assam Downtown University & Assam & BSW \& MSW & Private & 2010 \\
\hline 12 & $\begin{array}{c}\text { Higher and Technical Institute of } \\
\text { Mizoram }\end{array}$ & Mizoram & BSW & $\begin{array}{l}\text { Affiliated to Mizoram } \\
\text { University. }\end{array}$ & 2010 \\
\hline 13 & Assam Don Bosco University & Assam & MSW & State & 2011 \\
\hline 14 & Tata Institute of Social Sciences & Assam & M.A. in Social Work & Deemed & 2012 \\
\hline 15 & Don Bosco College Maram & Manipur & BSW & Private & 2012 \\
\hline 16 & $\begin{array}{l}\text { University of Sciences and } \\
\text { Technology }\end{array}$ & Meghalaya & BSW \& MSW & State & 2011 \\
\hline 17 & $\begin{array}{c}\text { NEF College of Management and } \\
\text { Technology }\end{array}$ & Assam & BSW \& MSW & $\begin{array}{l}\text { Affiliated to Dibrugarh } \\
\text { University }\end{array}$ & 2012 \\
\hline 18 & NERIM & Assam & MSW & & 2014 \\
\hline 19 & Himalayan University & $\begin{array}{l}\text { Arunachal } \\
\text { Pradesh }\end{array}$ & MSW & State University & 2014 \\
\hline 20 & Brahmaputra University & Assam & MSW & Private & 2014 \\
\hline 21 & Tezpur University & Assam & MSW & Central University & 2014 \\
\hline 22 & Peace centre & Nagaland & MSW & Private & 2014 \\
\hline
\end{tabular}

For many years students from Northeast studied Social Work in Institutions outside the region and many ended up working outside the region. Nevertheless a few came back to their hometown or state to seek employment either in government or non government institutions. The main reason for this seems to be that during the 1990s till early 2000s, there was less scope for trained social workers to avail work in the region and if there were opportunities, the minimal financial remuneration was not attractive enough. Thus most preferred to work outside the region. Another fact also relates to non recognition of Social Work as a profession by the people in the region. It was only recently that people became aware about social work as a profession. Following this, students started opting for social work education offered by various institutes and after passing out from various social work programmes they started working in NGOs. Until recently the NGOs in the region did not have trained social worker with the exception of some National and International NGOs. However the awareness among people and students about social work education is still wanting.
Nevertheless, it must be noted that since the past two-three years the trend towards recognising social work education as an professional and career option is picking up pace with many institutions offering social work programmes. These initiatives received a further fillip with the entry of the Tata Institute of Social Sciences (TISS) in Guwahati, Assam. Currently there are many students who have started opting for Social Work programmes as compared to other traditional social science disciplines such as Sociology, Political Sciences, etc. Another important factor relates to employability which makes social work programmes attractive as many of the Social Work graduates are absorbed in jobs whether in Governmental or Non-Governmental organisation. In comparison to disciplines of the Social Sciences, the possibility of being employed after a Postgraduate degree in Social Work is quite high. This employability factor seems to have contributed greatly towards mainstreaming of social work education in the region. For instance institution like TISS have campus placement where many NGOs from across the country and 
Governmental organisation come for recruiting students. Another aspect is that most of the graduate social work students are absorbed in regional based NGOs. These factors have contributed in attracting the students to opt for social work profession and also in streamlining the profession in the region.

However even though there has been a drastic increase in institutions offering social work programmes, these institutions are mostly confined to the State of Assam, which currently has ten institutions out of twenty two in the whole of Northeast. Meghalaya has four institutions and other states like Manipur, Nagaland and Mizoram have two each while Arunachal Pradesh has one institution. It is interesting to note that other states like Tripura and Sikkim do not have institutions that offer Social Work programmes so far. A fact that must be taken into consideration is that most of the Institutions offering Social Work programmes are private or affiliated to University and in some case institutions where only Sciences and Management programme are offered, Social Work education is also offered as part of their programme. On this count certain questions arises related to the intersection of Social Work Education and the Science / Management stream. Is it because Social Work education has become marketable? Or is it that social work education is seen as an outreach for trainees in other streams?

Data from field studies conducted by the author shows that most of the students who are studying social work in the Institutions or Universities are mostly from the region. Exceptions are in the case of TISS Guwahati campus that has $34 \%$ reserved for outside the region and $66 \%$ reserved for the students from the region. The TISS Guwahati Campus has students from different parts of the country. However students in the other social work institutions are mostly from the region with the exception of one or two students. The author while collecting data on the said subject found out that most of the students from the region (at least $97 \%$ of the students) whom the author has interacted wants to work in the region or go back to their own state and work. Another interesting finding is that majority of the students from outside the region who are studying social work in the region prefer to go back outside the region after the completion of their studies. Some factors indicated was less salary within the region in comparison to other regions plus the political turmoil and insurgencies problem engulfing the region.

\section{Challenges}

In the Northeast out of the present 22 institutions offering Social work, their intake of students vary according to their Instituions/Universities capacities. The TISS Guwahati offers Social Work programmes in four specialisation i.e Counselling (CS), Public Health (PH), Livelihood \& Social Entrepreneurship (LSE) and Community Organisation and Development practice (CODP), with an intake strength of seventy students for all the specialisations divided accordingly (20 each for LSE \& CODP and 15 each for CS and PH). Assam University, Silchar has 200 students in BSW and 73 in MSW. Likewise the number of students vary from 40-80 per batch. Altogether out of the 22 social work institutions, on an average, there are around 500 to 600 social work students graduating per year. At this juncture, there are enormous challenges for Social Work as a profession pertaining to its curriculum especially on field work placements, employability and overall quality of trained professionals. As Siddiqui (2001) argues that social work education currently suffers from lack of focus in terms of its professional identity. It should become more focused in terms of specific skills it wishes to impart to its learners. It should prepare students for specific professional tasks identified as developmental or curative rather than becoming too ambitious.

At the Northeast zone consultation on Social Work education, it was discovered that there were many issues and challenges faced by different Institutions/Universities from different states. Nevertheless it was learned that increasing number of students are opting for social work course as compared to four or five years back. There has been increasing numbers of Institutions offering social work course both in graduate and postgraduate level. This consultation was held on March 2012 at TISS Guwahati Campus and was the first regional (Northeast) consultation that has taken place with regards to social work education. The consultation was organised under the banner of National Network of Schools of Social Work. A total number of eleven institutions participated in the consultation. Among these institutions, five offered only Bachelor of Social Work (BSW); six institutions offered both BSW and MSW programmes and three institutions offered postgraduate programme. Further two Institutions offered BSW, MSW, Mphil and $\mathrm{PhD}$ programmes and one Institution offered only Mphil programme. The states represented in the consultation are Assam, Meghalaya, Manipur and Mizoram.

It was noted during the consultation that each department, college or institution vary in terms of methodology in relation to students' selection process, students' intake, curriculum, pedagogy, field work structure, faculty-student ratio, assessment and placement. Social work education has developed its own unique standards in different states of the region. Each state has its own unique contextual challenges and opportunities in regards to social work education. Though there are differences and varied opinions, there are also similarities in specific areas like: (1) Identity for Social Work Education (2) Quality concept of Social Work Education (3) Values \& Ideologies of Social Work and redefining the same (4) Employability (5) Teaching Methodology and success models.

There are numerous issues and challenges in the context of social work in northeast region and as the profession is still in its nascent stage, there is need to re-look and re-learnt from the other institutions that have grown through many phases and might probably have pass such. Some important 
challenges to Social work education in the region that needs immediate attention are discussed below:

\section{Social Work' as a Profession}

The word 'social work' is not new to the region. Politicians, local leader, community leader or someone who works for the people are known as Social Workers or so they claim to be. Interestingly, the layman's perception is located at such a level accepting the terminology to apply to everyone who is socially engaged. In this context, Social Work as a profession is yet to receive an acceptance and thus remains vague and unknown to most people of the region. In the report of National Network of Schools of Social work for Quality Enhancement of Social Work Education in India, the report positions Social Work as a Profession in northeast as suffering from being fully developed pertaining to a lack of awareness and understanding of the social work profession by other professionals. Social workers are generally considered 'sidekicks of politicians'. Societal recognition of social work as a profession in the region is minimal as people think that social work is synonymous with cleaning roads, drains and markets or running projects etc. There is lack of regulatory body as well as an active professional and educator's forum. Therefore an accepted criterion / framework for setting the standards of social work education in the region remain vague and nonexistent. Though the number of Social Work programmes is increasing, there is a need to streamline Professional Methods, Values, and Ethics that helps the profession qualify as one. Mass awareness both at the micro and macro level, career guidance, orientation and also involvement of the Government agencies is a strategy that can be adopted by each of the educational institutions both at the state and regional level. As compared to other region of India, Social work still needs to be defined in the process of the contextual reality of the region. Currently there are many 'dropout' and 'blind out' students who enrolled in social work courses just because it is a new profession in the region with promises of job opportunities after graduation.

\section{Curriculum}

Most social work curriculum needs to respond to social realities of the region without sacrificing the minimal core of social work education whilst capturing the dynamism of the local realities. Discussion on the same veers to the argument that most of the curriculum in the region follows a 'copy and paste' curriculum with least contextual reflexivity making it irrelevant to the Northeastern region which has its own unique and complex environment.

The profession of social work today needs to adopt a more radical approach. There have been debates in India arguing for a shift in the paradigm and approaches in social work education from a remedial focus to a more emancipatory development thrust. Social work education in India should be tailored to respond to the needs of the majority suffering population and not merely to a peripheral group (Bodhi,
2011). Most of the institutes in the region offer generic social work without specialisation. Looking at the diverse nature of the realities, there is a need for specialisation that allows more efficacious and deeper understanding. Specialisation of the course can be based on organisational / sectoral conceptions such as Community Development, Health, Social Entrepreneurship, Counselling, Governance, Management of Non-profit Organisation, etc. This will not only equipped the students better in a particular thematic area but will also equip him/her with greater degree of expertise which will enable him/her to deliver more effectively in the field.

\section{Field Work}

Field work is one of the important components in Social work education. Currently the debate on what field should be and on what ideological and perspectives should one positioned the field is yet to take place because of the challenges at hand faced by the Institutions with regards to placement of students for fieldwork in organisations in the region. Supervisors who are qualified are amiss and there are very few agencies in Northeast which have trained social workers for student's supervision. Therefore most organisations lack an understanding about the fieldwork component in social work training. Besides this, local political and social conditions in the region as well as difficult geographical terrains, long distances and other impediments hamper fieldwork placements. There is a need to establish linkages with schools, hospitals, and government department apart from NGOs so that student can be placed for fieldwork in these settings.

To tackle these impediments it is recommended that block field work for student become more feasible. This structure of field work is currently being followed by TISS Guwahati campus. On the other hand, while there are many organisations in the region, yet due to the lack of trained social worker in the organisation, it is difficult to find supervisor. Thus there is a need for social work faculty to play a greater role in guiding student in the field by visiting the field work organisation regularly with an intention to also make organisation aware about the supervisory process.

\section{Placement}

With 500 to 600 Social Work graduates passing out in a year from the region, there is a major concern for the placement of these graduates. Further, most of the Institutions are private or affiliated to University and the course fees are very high. Some student take loans from the bank and some institution provide study loan for their students. However the numbers of recruiters for social work students is quite low. It is observed that most of the social work graduates are absorbed in government projects like National Rural Health Mission (NRHM), National Rural Livelihood Mission (NRLM), and in national and international NGOs. Few of graduates are absorb in teaching profession. Very few students are working in grass roots 
organisation, small NGOs and Community Based Organisation (CBOs) with minimal financial remuneration. Many social work graduates have also left their jobs due to low salaries and dissatisfaction with their work. The question now is will the region be able to provide jobs in another two to three years for over 1500 Social work graduates? This is a major challenge for the profession and only time will tell. Nevertheless there is tremendous scope for work in the region in Entrepreneurship and Research rather than focusing only on market driven and high paying NGOs jobs. In this context, employability of Social work graduates should be conceived beyond market driven or government jobs.

Apart from the challenges and issues that are discussed above there is also a need for networking among Social work educators towards sharing learning and challenges through seminars and consultation in order to enhance the quality of social work education in the region. It is noted in the regional consultation that social work educators' quality is poor, lack experience and thus impacting the pedagogy and teaching method. Little research is done by the faculty with least publication due to lack of competence plus excessive burden (skewed teacher-student ratio). This creates other difficulties affecting student's research guidance.

\section{Conclusions}

As noted by Saldanha (2008) Professional social workers in training offer a significant ray of hope in the face of darkness. If they are to be an important agency contributing to major social transformation, it is relevant that they be exposed to the basic causes of the darkness through a relatively comprehensive theory that has ideological and practice implications. Northeast today is faced with many challenges from rapid development, ethnic conflict, state and non-state conflict, unemployment, insurgencies and problem of governance. While showing rapid growth, it is also necessary to seriously reflect and introspect its role in producing agents of change. Given the complexity of the region and the sudden increase of Social Work Institutions in the region, the direction for social work education and its educators should be to deepen itself to its context and build a new liberator practice paradigm that will nurture students to respond to the social, political and economic realities brought about by complex and dynamic regional realities.

\section{Note}

The data presented in the table is collected from interaction with the faculty of respective Institutions/Universities and also information available in the official website.

\section{REFERENCES}

Bodhi, S.R. Professional Social Work Education in India: A Critical View from the Periphery (Discvussion Note), Indian Journal of Social Work Vol.72 (2), 2011, p.289-300

Gore M S (2011): Social Work and Social Work Education, Rawat Publications, New Delhi

Rao, V (2012): Political Context of Social Work, Indian Journal of Dalit and Tribal Social Work Vol.1 No.2 pp.14 to 34,

Botcha, R (2012): Problems and Challenges for Social Work Education In India: Some Recommendations, International Journal of Multidisciplinary Educational Research, Volume 1, Issue 3,

Saldanha.D.(2008). Towards a Conceptualization of Social Action Within Social Work: Teaching Social

Siddiqui, H.Y. (2001):Social Wrok Education: Some Unresolved Curriculum Issues, Indian Journal of Social Work, 62(3), pp $535-553$

Thomas, G (2010): Origin and Development of Social Work in India, School of Social Work

2013: Report of Consultation on Social Work Education, North East Zone, TISS Guwahati

2013: Report of National Network of Schools of Social Work for Quality Enhancement of Social Work Education in India, TISS, Mumbai 